\title{
Evaluation of date kernel oils and their effects on wheat flour characteristics.
}

\author{
By A.S. Elsakr \\ Grain and Bread Res. Section, Agric. Res. Center, Giza. Egypt.
}

\section{RESUMEN}

Evaluación de aceites de pepitas de dátiles y sus efectos sobre las características de harina de trigo.

Las pepitas de dátiles constituyen alrededor del $13 \%$ del fruto entero, y contienen cantidades moderadas de aceite con valores calóricos relativamente altos.

En este trabajo se han utilizado aceites de pepitas de dátiles Agwa blandas y Aprimi secas. Los resultados mostraron que los aceites de pepitas de dátiles Aprimi tienen altos niveles de ácidos caproíco y esteárico, $23^{\prime} 04$ y $18^{\prime} 40 \%$ respectivamente, mientras que los aceites de pepitas Agwa tienen niveles altos de ácidos caprílico y cáprico, $22 ' 31$ y 12 '20\%. Por otra parte los aceites Agwa alcanzaron valores elevados de materia insaponificable, esteroles y tocoferoles.

La adición de aceites de pepitas de dátiles secas y blandas no mejoró el poder de la harina de trigo pero incrementó su resistencia a la extensibilidad.

PALABRAS-CLAVE: Aceite de pepita de dátil (composición) Aceite de pepita de dátil (efecto de) - Harina de trigo.

\section{SUMMARY}

Evaluation of date kernel oils and their effects on wheat flour characteristics.

Date kernels constitute about $13 \%$ of the whole date fruit, and cotain moderate amounts of oils with relatively high caloric values.

Agwa soft and Aprimi dry date kernel oils were used in this work. Results showed that Aprimi date kernel oils have high levels of both caproic acid and stearic acid of 23.04 and $18.40 \%$ respectively, while Agwa kernel oils have high levels of caprylic acid and capric acid of 22.31 and $12.20 \%$. Moreover Agwa oils achieved higher amounts of unsaponifiable matters, sterols and tocopherols.

The addition of soft and dry date kernel oils did not improve the wheat flour strength but raised its resistance to extensibility.

KEY-WORDS: Date kernel oil (composition) - Date kernel oil (effect of) - Wheat flour.

\section{INTRODUCTION}

About two hundred varieties of date are knowen of which only 20 are of commercial value. The annual production of different varieties of dates in Egypt exceeds 126 million tons.

Dates contain high level of inverted sugars together with relatively low fat content which are considered a rich source of calories.

Palm date kernel oils are similar to coconut oils in terms of low iodine value that makes it good for food application and cooking.

Salem and Hegazi (1972) mentioned that the etherextract content of seeds of dry dates was $8.02 \%$.

Piskur (1966) stated that the fatty acids composition of lipid extracted from Mbocoya palm kernel included caproic $0.23 \%$, caprylic $6.0 \%$, pelargonic trace, capric $5.64 \%$, lauric $39.6 \%$, myristic $7.75 \%$, palmitic $7.75 \%$, stearic $31.3 \%$, oleic $29.1 \%$, and linoleic $4.8 \%$.

Bonifort and Naria (1965) found by chromatographic analysis that palm oil and olive oil had palmitic acid $12.7,11.2 \%$, stearic acid $2.6,2.0 \%$, oleic acid $18.8,76.0 \%$, and linoleic acid $1.9,8.5 \%$ respectively.

Ukhum (1987) found that the dominant fatty acids in the palm oil were palmitic acid $47.5 \%$ and oleic acid $37.3 \%$.

Fedeli (1966) encountered that the sterols of the oils of palm and palm kernels were B-sitosterol, stigmasterol and campesterol.

Lampugnani (1986) profiled that palm fruit extract contained campesterol, $\Delta$-7stigmasterol, sitosterol, $\mathrm{C}_{12-18}$ fatty acids and fatty alcohols.

Moreover, Majumdar et al (1986) studied the nutritional quality of fractioned randomized palm oil using rats and achieved that fractioned randomized palm oil can be regarded as a better dietary fat. Bolling et al. (1973) and Mostafa (1982) improved the loaf volume and rheological properties of wheat flour dough by using oils as additives.

The purpose of this study was to estimate the biochemical properties of date kernel oils to use it as 
human nutrient and to investigate its effects on the physical characteristics of dough.

\section{MATERIALS AND METHODS}

Two samples of palm date were obtained from the local market. These samples were Agwa soft date and Aprimi dry date.

The kernels of these dates were separated from dates manually. The obtained kernel samples were ground to pass from 20 mesh, and then kept in tight containers in refrigerator at $3^{\circ} \mathrm{C}$ for analysis.

The resulted ground samples were subjected to fat extraction by using hexane according to the method described in A.O.A.C. (1975). Oils extract was saponified (A.O.A.C., 1975) and the unsaponifiable matters were separated. Hydrocarbons were isolated and determined by a column chromatography as outlined in A.O.A.C. (1975). Sterols were extracted and determined according to Emmerie and Engel (1939). Tocopherols in the unsaponifiable matters were colorimetericaly assayed following the method of Emmeri and Engel (1939). Acid, saponification and iodine values and refractive index were determined as detailed in A.O.A.C. (1975). Identification and determination of fatty acid contents in the oils of date kernels were determined by gas liquid chromatography after conversion to their methyl esters according to the method of Burchfield and Starrs (1962).

Table 1

Fat contents in date kernels.

\begin{tabular}{lccc}
\hline & Moisture & \multicolumn{2}{c}{ Fat } \\
Date & $\%$ & As is fresh & DWB* \\
& $\%$ & $\%$ & $\%$ \\
\hline Agwa & 5.69 & 6.73 & 7.14 \\
Aprimi & 4.33 & 7.41 & 7.75 \\
\hline
\end{tabular}

*DWB Dry weight bases.

Table II

Fatty acid contents in date kernel oils.

\begin{tabular}{lcc}
\hline Fatty acid & $\begin{array}{c}\text { Agwa } \\
\%\end{array}$ & $\begin{array}{c}\text { Aprimi } \\
\%\end{array}$ \\
\hline $\mathrm{C}-6$ & \multicolumn{1}{c}{$\%$} & 23.04 \\
$\mathrm{C}-8$ & 22.31 & 13.74 \\
$\mathrm{C}-10$ & 12.20 & 5.56 \\
$\mathrm{C}-11$ & 8.96 & 4.09 \\
$\mathrm{C}-12$ & 1.24 & 1.96 \\
$\mathrm{C}-13$ & 6.96 & 3.76 \\
$\mathrm{C}-14$ & 3.15 & 4.25 \\
$\mathrm{C}-14: 1$ & 4.29 & 1.80 \\
$\mathrm{C}-16$ & 6.67 & 1.80 \\
$\mathrm{C}-16: 1$ & 2.77 & 1.14 \\
$\mathrm{C}-18$ & 11.25 & 18.40 \\
$\mathrm{C}-18: 1$ & 2.57 & 4.41 \\
$\mathrm{C}-16: 2$ & 0.95 & 8.17 \\
$\mathrm{C}-18: 3$ & 3.62 & 8.17 \\
$\mathrm{C}-20$ & 3.53 & - \\
& & \\
\hline
\end{tabular}


Table III

Unsaponifiable matter contents in date kernel oil.

\begin{tabular}{lcccc}
\hline Date & $\begin{array}{c}\text { Unsaponifiable } \\
\text { matters }\end{array}$ & Sterols & Hydrocarbons & Tocopherol \\
& $\%$ & $\%$ & $\%$ & $\%$ \\
\hline Agwa & 7.14 & 2.50 & 4.29 & 0.066 \\
Aprimi & 6.28 & 2.96 & 0.95 & 0.032 \\
\hline
\end{tabular}

Table IV

Chemical and physical properties of date kernel oils.

\begin{tabular}{lcccc}
\hline Date & $\begin{array}{c}\text { Acid } \\
\text { value }\end{array}$ & $\begin{array}{c}\text { Saponification } \\
\text { value }\end{array}$ & $\begin{array}{c}\text { Iodine } \\
\text { value }\end{array}$ & $\begin{array}{c}\text { Refractive } \\
\text { index }\end{array}$ \\
\hline Agwa & 0.85 & 148.32 & 18.35 & 1.4439 \\
Aprimi & 0.88 & 141.10 & 25.49 & 1.4450 \\
\hline
\end{tabular}

Table V

Effect of addition date kernel oils to wheat flour (72\% extraction) on Farinograph test.

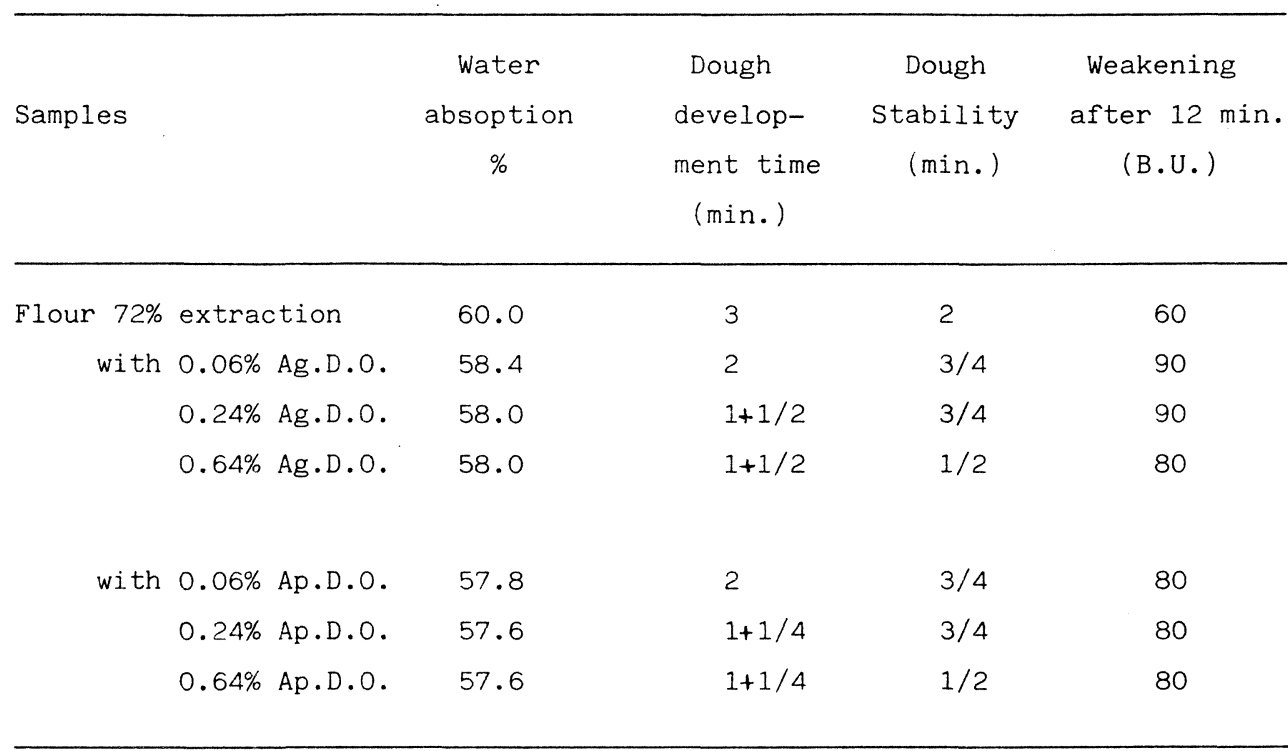

Date kernel oils, Agwa and Aprimi, were added at ratio of $0.06 \%, 0.24 \%$ and $0.64 \%$ to wheat flour.

Wheat flour $(72 \%$ extraction) was purchased from Mill and Bakery Co., Cairo, that was imported from France.

Dough mixing properties were obtained with Farinograph according to the method described in A.A.C.C. (1975). Dough resistance and extensibility assessed with Extensograph using flour dough containing $1 \%$ sodium chloride according to the defination in A.A.C.C. (1975).

\section{RESULTS AND DISCUSSION}

According to the data shown in table I, dry date kernels Aprimi had high fat levels: $7.75 \%$ and low moisture: $4.33 \%$ in comparison to that of soft date Agwa kernels. The composition of fatty acids shown in table II showed that the short chain fatty acids are present in higher amounts; i.e. caproic acid and caprylic acid in levels: $23 \%$ and $22.31 \%$ in Aprimi and Agwa date kernel oils respectively. Moreover, Aprimi date kernel oil contained linoleic acid and linolenic acid in higher percentages; $8.17 \%$ and $8.17 \%$ respectively 
Table VI

Effect of addition date kernel oil to wheat fluor (72\% extraction) on Extensograph test.

\begin{tabular}{rccr}
\hline \multicolumn{1}{c}{ Samples } & $\begin{array}{c}\text { Extensibility (E) } \\
(\mathrm{M})\end{array}$ & $\begin{array}{c}\text { Resistane } \\
(\mathrm{R}) \text { (B.U.) }\end{array}$ & $\mathrm{R} / \mathrm{E}$ \\
\hline Flour 72\% extraction & 125 & 440 & 3.52 \\
With 0.06\% Ag.D.0. & 88 & 980 & 11.14 \\
O.24\% Ag.D.0. & 98 & 920 & 9.39 \\
O.64\% Ag.D.0. & 98 & 900 & 9.18 \\
With 0.06\% Ap.D.O. & 67 & 780 & 11.64 \\
O.24\% Ap.D.O. & 64 & 700 & 10.94 \\
O.64\% Ap.D.O. & 59 & 600 & 10.17 \\
\hline
\end{tabular}

$$
\text { Ag.D.O.= Agwa date kernel oil. }
$$

when compared to Agwa date kernel oil, $0.95 \%$ and $3.62 \%$, respectively. The unsaponifiable matter contents presented in table III showed that Agwa date kernel oil had high contents of unsaponifiable matters and hydrocarbons; $7.14 \%$ and $4.29 \%$ respectively. Aprimi date kernel oil contain high sterols; $2.96 \%$.

These figures are higher than what was reported by United States, Department of Agriculture (1987), Piskur (1968), Benifort and Naria (1965) and Bailey (1946) add that may be due to variety differences of dates.

The physical and chemical properties of Agwa and Aprimi date kernel oils are shown in table IV. The refractive index was used for the determination of the degree of unsaturation. The difference in values were in the third decimal point. Aprimi date kernel oil has the highest acid value and iodine number, 0.88 and 15.49 while Agwa date kernel oil has the highest saponification number 148.32. The low iodine values were attributed to low content of unsaturated fatty acids. These results obtained were in agreement with those of Bailey (1946).

Table $\mathrm{V}$ shows that the addition of Aprimi dry date kernel oil at any level to wheat flour $72 \%$ extraction decreased the water absorption more than the addition of Agwa date kernel oil. Also the addition of Agwa and Aprimi oils did not improve the dough quality as the dough development time and dough stability were decreased. It is clear from this table that the addition of soft and dry date kernel oils weakened the wheat flour as the weakening values raised.

The data mentioned in table $\mathrm{VI}$ indicate superiority of the addition of Agwa soft date kernel oil at $0.064 \%$ level to wheat flour as it had the high resistance to extensibility compared with the other two levels and to the Aprimi dry date kernel oil at the levels used in this study.

\section{Ap.D.O.= Aprimi date kernel oil.}

It therefor could be concluded that palm date kernel oil is rich in saturated fatty acids and sterols that are plant sterols.

As quoted by Department of Agriculture (1987) that palm date kernel oil is among the most highly saturated and artery-damaging fats known, so this fat should not be used commercially in such foods as cookies, cakes, doughnuts, cereals and nondairy creamers.

\section{REFERENCES}

1. A.A.C.C.- American Association of Cereal Chemists.- Approved Method of the AACC. The Association. St. Paul, Minn., 1975.

2. A.O.A.C.- Official Methods of Analysis of the Association of Official Agricultural Chemists.- Published by the AOAC Benjamin Franklin Sta., Washington, D.C., 1975.

3. Bailey, A.- Industrial Oil and Fat Products.- Intersci. Publishers Inc., N. Y., 1946.

4. Bolling, M., El-Baya, A.W. and Zwengelberg, H.- Hetreide Mahl. Brot. 27 (1973) 92 (C. F. Adv. Food Sci. 23 (1973) 188).

5. Bonifort, L., and Naria, L.-Ann Tst. Super-Sanita.-1 (1965) 1 6,363 ITAL, (C.F. Chem. Abs., (1965016623F).

6. Burshfield, A. E. and Starrs, E. E.- Biochemical Application of Gas Chromatography.- Academic Press, LONDON, (1962).

7. Department of Agriculture, United States. Agriculture Research Service.- Technical Bull., Washington D. C., 1987.

8. Emmeri, A. and Engel, C.- Nature 42 (1962) 873.

9. Fedeli, E., Lanzani, A., Capella, P. and Jacini, Y.- "Triterpene Alcohols and Sterols of Vegetable Oils".- J. Am. Oil Chemists'Soc. 43 (1966) 254-256.

10. S.P.A. Lampugnani Farmaceutici.- I. T. Appl., 86/19 (1986) 903, $10 \mathrm{pp}$.

11. Majumdar, S., Bhattecharyya, A. C. and Bhattecharyya, D. K."Nutritional Evaluation of Fractionated Randomised Palm Oil and Vanaspati".- J. Food Sci. Technol. 23 (1986) 321-325.

12. Ukhum, M. E.- Hum. Nutr. Food Sci. Nutr. 41 F (2) (1982) 584.

13. Mostafa, M. K.- Egypt. J. Food Sci. 10 (1-2) (1982) 29.

14. Piskur, M. M.- J. Am. Oil Chemists'Soc. 4518 (1982) 584.

15. Salem, S. A. and Hegazi, S. M.- J. Sci. Food Agr. 22 (1972) 632.

(Recibido: Septiembre 1990) 